УДК 378.018 .43

DOI https://doi.org/10.32782/apv/2021.3.20

\title{
Ірина РАСВСЬКА
}

кандидат педагогічних наук, дочент кафедри теорії та методики дочкільної та початкової освіти, Херсонський держсавний університет, вул. Університетська, 27, м. Херсон, Украйна, 73003

ORCID: 0000-0002-4582-2839

\section{Альона БАЛЬОХА}

викладач кафедри теорії та методики дошкільної та початкової освіти, Херсонський державний університет, вул. Університетська, 27, м. Херсон, Україна, 73003

ORCID: 0000-0003-4256-5758

Бібліографічний опис статті: Раєвська, І., Бальоха, А. (2021). Розвиток дослідницьких умінь майбутніх учителів початкових класів в умовах дистанційного освітнього процесу. Acta Paedagogica Volynienses, 3, 133-138, doi: https://doi.org/10.32782/apv/2021.3.20

\section{РОЗВИТОК ДОСЛІДНИЦЬКИХ УМІНЬ МАЙБУТНІХ УЧИТЕЛІВ ПОЧАТКОВИХ КЛАСІВ В УМОВАХ ДИСТАНЦІЙНОГО ОСВІТНЬОГО ПРОЦЕСУ}

Статтю присвячено вивченню впровадження інформаційно-комунікаційних технології в освіті, а саме розробці електронних освітніх ресурсів, які здатні задовольняти освітні потреби здобувачів вищої освіти як під час очного, так і дистаниійного навчання.

Метою статті є визначення особливостей розвитку дослідницьких умінь майбутніх учителів початкових класів в умовах сучасного освітнього середовища та розкриття можливостей дистанційних освітніх ресурсів у реалізачї означеної проблеми.

Акцентовано на тому, щзо епідеміологічна ситуачія в краӥні й світі, пов'язана з поширенням Соvіd-19, вимагає забезпечення реалізації освітніх послуг дистаниійно. Тому постає питання не лише якості підготовки здобувачів вищої освіти, а й створення відповідних умов, які б сприяли оволодінню сучасними методами пошуку, обробки і використання інформації, вмінням ї̈ інтерпретувати й адаптувати у своїй професійній діяльності. Наголошується на тому, щз розвиток дослідницьких умінь відбувається у процесі розв 'язання педагогічних завдань i стають у нагоді вчителю при проведенні наукового пошуку. Для їх використання вчителю необхідно будувати свою діяльність відповідно до загальних правил евристичного пошуку.

Розглянуто особливості використання контенту електронного навчально-методичного ресурсу «Wеbмультимедіа енщиклопедія з дисциплін природничого цииклу», який функціонує на педагогічному факультеті Херсонського державного університету. На прикладі освітньої компоненти «Методика навчання освітньої галузі «Природознавство»» як складової частини електронного навчально-методичного ресурсу схарактеризовано деякі розділи курсу: «Практичний модуль», «Мультимедіа галерея», «Відеотека» та їх зв'язок. Зосереджено увагу на змісті завдань природничого спрямування для розвитку дослідницьких умінь у майбутніх учителів початкових класів.

Ключові слова: дослідницькі уміння, майбутній вчитель початкових класів, освітнє середовище, інформаційно-комунікаційні технологіi, Wеb-мультимедіа енциклопедія з дисциилін природничого изикл.

\section{Iryna RAEVSKA}

Candidate of Pedagogical Sciences, Associate Professor at the Department of Theory and Methods of Preschool and Primary Education, Kherson State University, University str. 27, Kherson, Ukraine, 73003

ORCID: 0000-0002-4582-2839

\section{Alona BALOKHA}

Lecturer at the Department of Theory and Methods of Preschool and Primary Education, Kherson State University, University str.27, Kherson, Ukraine, 73003

ORCID: 0000-0003-4256-5758

To cite this article: Raevska, I., Balokha, A. (2021). Rozvytok doslidnytskykh umin maibutnikh uchyteliv pochatkovykh klasiv $\mathrm{v}$ umovakh dystantsiinoho osvitnoho protsesu [The development of the investigation skills of future teachers of primary school in the conditions of the distant educational process]. Acta Paedagogica Volynienses, 3, 133-138, doi: https://doi.org/10.32782/apv/2021.3.20 


\section{THE DEVELOPMENT OF THE INVESTIGATION SKILLS OF FUTURE TEACHERS OF PRIMARY SCHOOL IN THE CONDITIONS OF THE DISTANT EDUCATIONAL PROCESS}

The article is dedicated to the studying of the providing of the informational and communicative technologies in education, namely to the working out of the electronic educational resources which are able to satisfy the educational demands of the applicants of Higher education as during the full-time instruction and during the distant studying.

The aim of the article is the definition of the peculiarities of the development of the investigation skills of future teachers of primary classes in the conditions of modern educational environment and the opening of possibilities of the distant educational resources in the realization of the defined problem.

It is paid an attention that the epidemic situation in the country and in the world which is connected with the expansion of Covid-19 demands the providing of a realization of the educational services distantly. Thus, it is a question arisen not only concerning the training of the applicants of Higher education and also of the creation of new conditions which influence on the mastering of the modern methods of a research. For its usage a teacher needs to construct his activity in accordance with the general rules of the heuristic research.

It is considered the features of the usage of content of electronic studying and methodical resource «Web-multimedia encyclopedia on the disciplines of natural cycle» which makes a function at the Pedagogical faculty of the Kherson State University. In the example of educational component "Method of studying of the educational branch "Natural science»» as a part of the electronic studying and methodical resource, it is characterized some of the parts of the course: «Practical module», "Multimedia gallery», "Video» and its connection. It is concentrated an attention on the content of the tasks of the natural orientation for the development of the investigation skills of future teachers of primary school.

Key words: investigation skills, future teacher of primary classes, educational environment, informational and communicative technologies, Web-multimedia encyclopedia on the disciplines of the natural cycle.

Актуальність проблеми. Реформування освіти ставить високі вимоги до особистості вчителя, зокрема вчителя початкових класів. Результати наукових пошуків та аналіз освітньо-нормативних вимог доводять, що роль вчителя змінюється, актуальності набуває вміння реалізувати власну професійну компетентність, виконання ключових функцій.

Затребуваним стає фахівець, що володіє загальними та дослідницькими вміннями, здатний вирішувати власні освітні потреби і використовувати отримані результати на практиці (Раєвська, 2010).

Законом України «Про вищу освіту» (2020) регламентовано створення освітнього середовища, орієнтованого на задоволення потреб та інтересів здобувачів вищої освіти, зокрема викладання та навчання, відповідно до європейських стандартів отримання знань, надання можливостей для формування індивідуальної освітньої траєкторії (Закон України «Про вищу освіту», 2020).

На нинішньому етапі цивілізаційного поступу актуальним завданням підготовки майбутніх учителів початкових класів $є$ розвиток у них дослідницьких умінь як необхідної умови підвищення професійного рівня, орієнтації у широкому арсеналі інноваційного руху, наукових розробках, якісного навчання та виховання здобувачів освіти у початковій школі (Раєвська, 2017, С. 34-47).
В полі наших наукових інтересів - розвиток дослідницьких умінь майбутніх учителів початкових класів в системі вищої освіти, а саме в умовах іiї дистанційної організації.

Відтак, мета нашого дослідження полягає у визначенні особливостей розвитку дослідницьких умінь майбутніх учителів початкових класів в умовах сучасного освітнього середовища та розкритті можливостей дистанційних освітніх ресурсів в реалізації означеної проблеми.

Аналіз останніх досліджень і публікацій. Проблема розвитку дослідницьких умінь у майбутніх фахівців досліджувалася з різних аспектів і була об'єктом вивчення багатьох науковців: В. Базелюка, В. Краєвського, Н. Кузьміної, А. Маркової, А. Марон, Г. Сухобської, Л. Коржової, М. Князян, Р. Попової, Р. Шейразіної (Раєвська, 2017, С.7-30).

Серед шляхів професійної підготовки майбутніх учителів початкових класів $\epsilon$ впровадження в освітній процес закладів вищої освіти інформаційно-комунікаційних технологій. Такою проблемою займалися В. Биков, Н. Воропай, М. Жалдак, Ю. Жук, В. Ізвозчиков, Е. Карпова, О. Коваль, В. Коткова, В. Монахова, Н. Морзе, Л. Пермінова, Л. Петухова, О. Саган, О. Співаковський (Бальоха, 2020).

Узагальнюючи наукові пошуки вітчизняних та зарубіжних учених, можна зробити висновок, що системні дослідження розвитку дослідниць- 
ких умінь учителів початкових класів в умовах сучасного освітнього середовища практично не проводились.

\section{Виклад основного матеріалу дослідження.}

Аналіз наукових досліджень дає підстави стверджувати що «розвиток» передбачає процес якісних змін особистості, та знаменує перехід від простого до складного, від нижчого до вищого. Він не тотожний процесу здобуття освіти, бо має цілком іншу природу: якщо освіта передбачає засвоєння і нагромадження інформації, то розвиток - певну перебудову і вдосконалення «функцій і якостей» людини. Також означене утворення, по-перше, пов'язано 3 логікою наукового дослідження, а саме: 3 висуванням гіпотези, виділенням істотних ознак досліджуваного явища, вибором методів дослідження тощо; по-друге, це - інтеграційне надбання особистості, що відбиває іiі здатність до адаптації й наукового пошуку та формується за допомогою дослідницької діяльності при наявності відповідних компетенцій.

У нашому дослідженні ми розглядаємо розвиток дослідницьких умінь вчителів, як закономірний i цілеспрямований процес якісних змін у професійних компетенціях, мотивах і особистісних якостях. Необхідність володіння дослідницькими уміннями визначається самою природою педагогічної діяльності, в зміст якої включено дослідження педагогічного процесу і його результатів (М. Кларін, В. Краєвський, Н. Кузьміна, Ю. Кулюткин, В. Сластьонін, 3. Шершнева тощо). За визначенням Л. Нікітіної, дослідницькі вміння - це вміння застосовувати відповідний прийом наукового методу в умовах рішення педагогічного, методичного чи власного дослідницького завдання (Раєвська, 2017, С.90-98).

За результатами наукових пошуків, окрім визначення, нами виокремлено критерії дослідницьких умінь майбутніх учителів початкових класів та їх показники:

пошукові вміння: вести пошук необхідної інформації, користуватися довідковою літературою, електронними каталогами; обробляти, зберігати, узагальнювати, систематизувати, інтерпретувати отриману інформацію; порівнювати різні точки зору на одну й ту ж проблему; складати план, тези, конспект тощо;

операційні вміння: визначати мету і об'єкт дослідження; формулювати проблему, яку потрібно вирішити в ході проведеного навчального дослідження; уміння ставити завдання для досягнення мети;

проєктувальні вміння: прогнозувати результати дослідження, визначати критерії успішності проведеної роботи; складати звіт про виконану роботу; створення нових продуктів, можливих варіантів майбутньої діяльності;

комунікативні вміння: уміння вести дискусію, відстоювати свої позиції, уміння співпрацювати у процесі дослідницької діяльності; вміти презентувати результати досліджень;

рефлексивні: уміння здійснювати самоаналіз і самооцінку результатів власної дослідницької діяльності в ролі вчителя (Раєвська, 2010).

Визначені структурні складові частини дослідницьких умінь майбутніх фахівців формуються особистісно у процесі здобуття освіти та професійної діяльності. А опанування ними дають можливість молодим фахівцям працювати і бути успішним у швидко змінюваному світі, дозволяють знаходити, аналізувати, використовувати нову інформацію 3 метою підвищення кваліфікації, допомагають адаптуватися до динамічних умов сьогодення, набувають соціальної мобільності і впевненості на ринку праці.

3 огляду на вищезазначене, заклади вищої освіти (далі 3ВО) покликані створити умови для підготовки педагога якісно нового типу, зі сформованими дослідницькими вміннями.

Традиційно організація дослідницької діяльності здобувачів вищої освіти у ЗВО має реалізацію у: навчально-дослідницькій роботі, яка передбачає написання курсових робіт, випускних кваліфікаційних робіт за освітніми програмами; власне дослідницькій діяльності здобувача вищої освіти, яка здійснюється під керівництвом наукового керівника або самостійно; роботі здобувачів вищої освіти у проблемних групах; активному залученні їх до роботи у семінарах, круглих столах, науковопрактичних конференціях різного рівня; участі у всеукраїнських конкурсах наукових робіт здобувачів вищої освіти.

Означені види робіт доводять, що рівень сформованості дослідницьких умінь залежить від умов, створених на базі ЗВО. Однак вони не вичерпують усіх ресурсів на шляху до розвитку визначеного вміння у майбутніх фахівців, враховуючи швидкі зміни розвитку освіти та суспільних запитів. 
Найбільш сприятливими умовам для розвитку дослідницьких умінь у майбутніх учителів початкових класів є освітнє середовище 3ВО, як сукупність мотивів і впливів на професійно зростаючу людину, а також, як передумова для реалізації іiі подальших наукових чи професійних досліджень (Биков, 2010). Тому постає питання розвитку дослідницьких умінь також під час опанування освітніх компонент.

Враховуючи активну інформатизацію системи освіти та перехід на дистанційну форму освітнього процесу, у зв' язку з поширенням епідеміологічної ситуації, сьогодні інформаційнокомунікаційні технології носять імперативний характер та $\epsilon$ рушійним фактором розвитку освітнього середовища (Sagan et al., 2020).

Застосування інформаційно-комунікаційних технологій в освіті, впровадження викладачами комп'ютерно-орієнтованих методик навчання, використання відкритих освітніх ресурсів $\epsilon$ провідними чинниками мотивації здобувачів вищої освіти до професійного становлення та необхідною умовою під час переходу на дистанційну освіту. Це допомагає вчити та навчатися, робить освітні ресурси доступнішими, особливо для тих, кому бракує навчальних матеріалів, розвиває культуру навчання, творення, обміну і співпраці у швидкозмінному потоці інформації, формуючи таким чином позитивне ставлення до освітнього процесу, бажання навчатися, здобувати відповідні компетенції і як наслідок - забезпечує формування позитивної мотивації до учіння в новому інформаційному освітньому просторі та сприяє розвитку дослідницьких умінь у здобувачів вищої освіти.

Результатом інформатизації освітнього процесу є розробка та укомплектування електронних освітніх продуктів. Прикладом такого продукту виступає Web-мультимедіа енциклопедія 3 дисциплін природничого циклу, яка $\epsilon$ частиною динамічного інформаційно-комунікаційного педагогічного середовища на педагогічному факультеті Херсонського державного університету. Функціонує на рівні вже діючих електронних ресурсів педагогічних освітніх компонент для оптимізації процесу формування професійних компетентностей майбутніх фахівців і архітектура яких, обрана за основу. Перевагою такого ресурсу в сучасних освітніх умовах $\epsilon$ забезпечення дистанційного та очного управління процесом організації природничої діяльності здобувачів вищої освіти, також дозволяє проводити моніторинг результатів процесу, координувати й контролювати іiі (Бальоха, 2020).

3 урахуванням принципу системності у питанні формування природознавчої компетентності майбутніх учителів початкових класів у 3ВО, навчальна платформа «Webмультимедіа енциклопедія 3 дисциплін природничого циклу» представляє собою комплекс природничих освітніх компонент відповідно до програми СВО «бакалавр» 3 повним методичним та мультимедійним забезпеченням та програму навчальної (природничої) практики.

Вебсайт створено на базі навчальної платформи Moodle 3.6.2+. Кожна з освітніх компонент відзначається єдиною архітектурою, що сприяє швидкому та легкому орієнтуванню для користувачів та викладачів.

Для ознайомлення 3 можливостями електронного ресурсу у процесі розвитку дослідницьких умінь майбутніх учителів початкових класів, пропонуємо характеристику деяких розділів курсу (освітньої компоненти) «Методика навчання освітньої галузі «Природознавство»».

Варто зупинитись на особливостях функціонування такого розділу Web-мультимедіa енциклопедї з дисциплін природничого изиклу як «Практичний модуль». Плани практичних занять розміщені за допомогою модулю «Сторінка», що дозволяє користувачеві швидко отримати доступ до завдань відповідної теми у будь який зручний час. Перевагою такого модулю є можливість зміни змісту завдання для здобувачів вищої освіти з відповідної теми, або виокремлення іiї для самоопрацювання.

До кожної сторінки плану практичного заняття прикріплено додаткові модулі діяльності «Завдання». Таке виокремлення завдань зумовлено кількома потребами. По-перше, $\epsilon$ методичний супровід щодо виконання завдань, передбачених планом. У запропонованих «Завданнях» викладач має можливість надати методичні рекомендації здобувачам освіти до кожного із завдань плану практичного заняття до якого вони приєднані. По-друге, такий модуль дозволяє викладачеві сформулювати та запропонувати додаткові, диференційовані завдання, збирати роботи, оцінювати ïx, залишати відгуки на виконані роботи. Варто 
відзначити, що така організація діяльності чітко орієнтована на дисциплінованість користувачів, які маючи необхідний інструментарій, самостійно визначають траєкторію, темп виконання поставленого завдання 3 урахуванням його дедлайну. А це своєю чергою впливає на мотивацію здобувачів вищої освіти щодо якості виконання завдання та його оцінки.

Здобувачі освіти, під час опрацювання модуля, мають можливість здійснювати пошук додаткової інформації з різних джерел, обробляти, зберігати, узагальнювати, систематизувати, інтерпретувати отриману інформацію; порівнювати різні точки зору на одну й ту ж проблему; складати план, тези, конспект.

Для прикладу практичним модулем передбачена тема «Методична різноманітність проблемних завдань». Для підготовки до практичного заняття користувачам пропонується так завдання: «Сформулюйте 1-2 пізнавальних завдання до поданих тем. Для виконання завдання, перегляньте Вебінар, що розміщений у рубриці «Відеотека» курсу та зміст підручників для початкової школи. Складені вами завдання, завантажте на сайт та відправте для оцінки». Таке завдання не містить прямого роз'яснення різновидів та змісту пізнавальних завдань природничого змісту, однак орієнтує користувачів на методичний матеріал, який необхідно самостійно розглянути, дослідити, при можливості використати додаткові джерела.

Варто зауважити, що завдання пов'язане 3 іншим розділом курсу (освітнього компоненту) - «Відеотека». Він містить відеоролики чи покликання на необхідні наукові джерела для розширення знань здобувачів вищої освіти чи додаткової інформації. Для формулювання пізнавальних завдань, користувач має самостійно переглянути відповідний вебінар, проаналізувати зміст, визначити різновиди пізнавальних завдань, які доречно застосовувати в початковій школі: завдання на класифікацію, визначення головного тощо. За аналогією скласти авторські завдання природничого змісту.

Однак варто зазначити, що для успішного виконання такого завдання, майбутні вчителі початкових класів мають провести власні дослідження з природознавства та вміти прогнозувати результати дослідження; вибирати критерії успішності проведеної роботи; складати звіт про виконану роботу. Складність запропо- нованої роботи полягає в тому, що пізнавальні завдання природознавчого змісту вимагають від майбутніх учителів початкових класів досить глибоких знань 3 різних природничих галузей. Відповідно, при виконанні завдання, здобувачі потребують самостійного повторення, розширення або вивчення деяких нових для себе тем чи інформації.

Також спікер у пропонованому вебінарі коментує пізнавальні завдання орієнтовані на середню школу, що вимагає від майбутнього вчителя початкових класів переосмислення та трансформації запропонованих спікером завдань для рівня початкової школи. Це спонукає до аналізу та пошуку додаткових джерел для реалізації завдання. Перший інструментарій, який пропонується здобувачеві вищої освіти розміщено в розділі «Мультимедіа галерея», який містить підручники з природознавства для початкової школи та матеріали педагогічної спадщини К.Д. Ушинського. Адже ретроспективний аналіз природничої освіти сприяє поглибленню розуміння майбутніх учителів початкових класів про іiї важливість у процесі навчання та розвитку підростаючого покоління. Саме така робота сприяє ефективному розвитку дослідницьких умінь у майбутніх фахівців, а «Web-мультимедіа енциклопедія $з$ дисциплін природничого циклу» створює таке освітнє середовище, яке мотивує здобувачів вищої освіти, систематизує їх освітню діяльність та регулює іiі у динамічному інформаційному просторі.

Висновки і перспективи подальших досліджень. Таким чином, основним змістом діяльності ЗВО повинно стати формування інноваційного освітнього середовища, що передбачає: зміну організації і змісту освіти з урахуванням iii дистанційної форми та потреб здобувачів вищої освіти, удосконалення професійного становлення майбутніх учителів початкових класів через опанування дослідницькими вміннями та інноваційними і дослідно-експериментальними видами діяльності.

Оскільки творчий підхід до педагогічної діяльності і володіння дослідницькими уміннями визначають успішність всього освітнього процесу, перспективою подальших наукових пошуків вбачаємо в уніфікації контенту Web-мультимедіа енииклопедї з дисциплін природничого ичиклу спрямованого на ефективний розвиток дослідницьких умінь у здобувачів вищої освіти. 


\section{ЛITЕРАТУРА:}

1. Olena Sagan, Svitlana Yakovleva, Elena Anisimova. Alona Balokha, Halyna Yeremenko Digital didactics as a new model in the theory of education. Revista inclusions. 2020. Vol. 7, número especial. P. 173-204.

2. Бальоха А. С. Створення інформаційно-комунікаційного педагогічного середовище у процесі підготовки майбутніх учителів початкових класів до реалізації природничої освітньої галузі в початковій школі. Актуальні питання гуманітарних наук. 2020. Вип. 33. Том 1. С. 257-261.

3. Биков В. Ю. Відкрите навчальне середовище та сучасні мережні інструменти систем відкритої освіти. Науковий часопис НПУ ім. М.П. Драгоманова. 2010. (9). Pp. 9-16. URL: http://lib.iitta.gov.ua/1159/1/B8.pdf

4. Вебмультимедіа енциклопедія з дисциплін природничого циклу. URL: http://webnc.kspu.edu/.

5. Закон України «Про вищу освіту» від 25.09.2020. - URL: https://zakon.rada.gov.ua/laws/show/1556-18\#Text

6. Закон України «Про освіту» від 05.09.2017. - URL: http://zakon.rada.gov.ua/laws/show/2145-19

7. Професійний стандарт за професіями «Вчитель початкових класів закладу загальної середньої освіти», «Вчитель закладу загальної середньої освіти», «Вчитель 3 початкової освіти (з дипломом молодшого спеціаліста)». URL: https://nus.org.ua/wp-content/uploads/2020/12/Nakaz_2736.pdf

8. Раєвська І. Особливості розвитку дослідницьких умінь учителів початкових класів у сучасному середовищі післядипломної педагогічної освіти. Педагогічний альманах. 2010. Випуск 6. С. 130-135.

9. Раєвська І. Розвиток дослідницьких умінь учителів початкової школи у системі післядипломної педагогічної освіти: теорія і практика : монографія. 2017. 215 с.

10. Типові освітні програми для закл. загальної середньої освіти: початкова школа: іншомовна освіта + Державний стандарт початкової освіти. Київ : ТД «ОСВІТА-ЦЕНТР+», 2018. 80 с.

\section{REFERENCES:}

1. Sagan, O., Yakovleva, S., Anisimova, E., Balokha, A. \& Yeremenko, H. (2020). Digital didactics as a new model in the theory of education. Revista inclusions, 7, 173-204 (in Spain).

2. Balokha, A.S. (2020). Stvorenia informatsiino-komunikatsiinoho pedahohichnoho seredovyshcha u protsesi pidhotovky maibutnikh uchyteliv pochatkovykh klasiv do realizatsii pryrodnychoi osvitnoi haluzi v pochatkovii shkoli [Creating an information and communication pedagogical environment in the process of preparing future primary school teachers for the implementation of natural education in primary school]. Aktualni pytania humanitarnykh nauk - Current issues of the humanities, 33, (Vols. 1), 257-26 (in Ukrainian).

3. Bykov, V.Yu. (2010). Vidkryte navchalne seredovyshche ta suchasni merezhni instrument system vidkrytoi osvity [Open learning environment and modern network tools of open education systems]. Naukovyi chasopys NPU im. M.P. Drahomanova - Scientific journal of NPU named after M.P. Drahomanov, 9, 9-16. Retrieved from http://lib.iitta.gov. ua/1159/1/B8.pdf (in Ukrainian).

4. Vebmultymedia entsyklopediia $\mathrm{z}$ dystsyplin pryrodnychoho tsyklu [Web Multimedia encyclopedia from the disciplines of natural sciences]. Retrieved from http://webnc.kspu.edu/ (in Ukrainian).

5. Zakon Ukrainy «Pro vyshchu osvitu» vid 25.09.2020 [Law of Ukraine "On Higher Education" of 25.09.2020]. Retrieved from https://zakon.rada.gov.ua/laws/show/1556-18\#Text (in Ukrainian).

6. Zakon Ukrainy «Pro osvitu» vid 05.09.2017 [Law of Ukraine "On Education" of 05.09.2017]. Retrieved from http://zakon.rada.gov.ua/laws/show/2145-19 (in Ukrainian).

7. Profesiinyi standart za profesiiamy «Vchytel pochatkovykh klasiv zakladu zahalnoi serednoi osvity», «Vchytel zakladu zahalnoi serednoi osvity», «Vchytel z pochatkovoi osvity (z dyplomom molodshoho spetsialista)» [Professional standard for the professions «Primary school teacher of general secondary education», «Teacher of general secondary education», «Primary teacher (with a diploma of junior specialist)»]. Retrieved from https://nus.org.ua/wp-content/ uploads/2020/12/Nakaz_2736.pdf (in Ukrainian).

8. Raevska, I. (2010). Osoblyvosti rozvytku doslidnytskykh umin uchyteliv pochatkovykh klasiv u suchasnomu seredovyshchi pisliadyplomnoi pedahohichnoi osvity [Features of the development of research skills of primary school teachers in the modern environment of postgraduate pedagogical education]. Pedahohichnyi almanakh - Pedagogical almanac, 6, 130-135 (in Ukrainian).

9. Raevska, I. (2017). Rozvytok doslidnytskykh umin uchyteliv pochatkovoi shkoly u systemi pisliadyplomnoi pedahohichnoi osvity: teoriia i praktyka [Development of research skills of primary school teachers in the system of postgraduate pedagogical education: theory and practice]. Kherson: KVNZ «Khersonska akademiia neperervnoi osvity», 215 p. (in Ukrainian).

10. Typovi osvitni prohramy dlia zakl. zahalnoi serednoi osvity: pochatkova shkola: inshomovna osvita + Derzhavnyi standart pochatkovoi osvity [Typical educational programs for zakl. general secondary education: primary school: foreign language education + State standard of primary education]. (2018). Kyiv: TD «OSVITA-TSENTR+», 80 p. (in Ukrainian). 